\title{
Religião: limites e horizontes de um conceito*
}

\section{Frederico Pieper ${ }^{* *}$}

\author{
A realidade "mesma" não fala de si. Tem \\ necessidade de um porta-voz - quer dizer, \\ justamente, intérpretes motivados, que decidem como \\ representar sobre um mapa um território ao qual \\ tiveram acesso através de mapas mais antigos.
}

Gianni Vattimo

\section{Resumo}

No contexto brasileiro, há certo consenso de que o campo de estudos Ciências da religião é composto por vários métodos, que se articulam tendo em vista seu objeto: a religião. Para alguns autores nacionais, se há debate quanto aos métodos, haveria relativo acordo no que concerne ao objeto. Esse artigo busca justamente tematizar esse último aspecto, problematizando o conceito de religião. Isso será feito a partir de uma leitura crítica dessa noção, argumentando-se, inicialmente, que se trata de uma categoria moderna e não nativa. A partir do caráter situado do termo, alguns autores propuseram seu abandono, uma vez que não encontra correspondente na realidade. Desse modo, na segunda parte, o artigo apresenta e discute os limites dessa proposta, especialmente mostrando a sua falta de coerência. Por fim, o artigo busca responder à seguinte indagação: se não se pode tomar o conceito de religião de maneira naturalizada, o outro extremo, de propor seu abandono ou trocar por outras noções, também se depara com consideráveis limites. Então, para onde nos conduz a consideração crítica do conceito religião? O encaminhamento que o artigo propõe leva a pensar os conceitos, dentre eles o de religião, como aquilo que possibilita pensar certos fenômenos. Por mais que tenham limitações e sejam situados, são eles que abrem o horizonte para o entendimento de certos fenômenos. Portanto, sem deixar de reconhecer seu caráter situado, argumenta-se que o conceito de religião tem sua pertinência.

Palavras-chave: Teoria da Religião; Hermenêutica; Modernidade; Epistemologia.

* Uma versão preliminar desse texto foi publicado em SILVEIRA, Emerson; COSTA, Waldney de S. Rodrigues. A polissemia do sagrado. São Paulo: Fonte Editorial, 2015, p.31-54.

** Professor do programa de pós-graduação em Ciências da Religião da UFJF. Email: fredericopieper@gmail.com 


\title{
Religion: limits and horizons of a concept
}

\begin{abstract}
In the Brazilian context, there is a certain consensus that the field of Religious Studies is composed of several methods, which are articulated in view of its subject: religion. For some Brazilian authors, if there is debate about methods, there would be relative consensus about the subject. This article seeks precisely to thematize this last aspect, problematizing the concept of religion. This will be done from a critical reading of this notion, arguing initially that it is a modern category and not a native one. From the situated character of the term, some authors proposed its abandonment, since it does not find correspondent in the reality. Thus, in the second part, the article presents and discusses the limits of this proposal, specially showing its lack of coherence. Finally, the article seeks to answer the following question: if one cannot take the concept of religion in a naturalized way, the other extreme, of proposing its abandonment or exchange for other notions, also faces considerable limits. So where does the critical consideration of the concept of religion lead us? The article proposes to think the concepts, among them the one of religion, as what makes possible to think certain phenomena. However limited and situated they may be and, they open the horizon for the understanding of certain phenomena. Therefore, while recognizing its situated character, it is argued that the concept of religion has its relevance for the study of religion.
\end{abstract}

Keywords: Religion Theory; Hermeneutics; Modernity; Epistemology.

\section{Religión: límites y horizontes de un concepto}

\section{Resumen}

En el contexto brasileño, hay cierto consenso de que el campo de estudios ciencias de la religión está compuesto por varios métodos, que se articulan teniendo en vista su objeto: la religión. Para algunos autores nacionales, si hay debate en cuanto a los métodos, habría relativo acuerdo en lo que concierne al objeto. Este artículo busca tematizar ese último aspecto, problematizando el concepto de religión. Esto se hará a partir de una lectura crítica de esta noción, argumentando, inicialmente, que se trata de una categoría moderna y no nativa. A partir del carácter situado del término, algunos autores propusieron su abandono, una vez que no encuentra corresponsal en la realidad. De este modo, en la segunda parte, el artículo presenta y discute los límites de esta propuesta, especialmente mostrando su falta de coherencia. Por último, el artículo busca responder a la siguiente indagación: ¿si no se puede tomar el concepto de religión de manera naturalizada, el otro extremo, de proponer su abandono o cambiar por otras nociones, también se depara con considerables limites? Entonces, ¿hacia dónde nos conduce la consideración crítica del concepto religión? El encaminamiento que el artículo propone lleva a pensar los conceptos, entre ellos el de religión, como aquello que posibilita pensar ciertos fenómenos. Por más que tengan limitaciones y sean situados, son ellos quienes abren el horizonte para el entendimiento de ciertos fenómenos. Por lo tanto, sin dejar de reconocer su carácter situado, se argumenta que el concepto de religión tiene su pertinencia.

Palabras clave: Teoría de la Religión; hermenéutica; la modernidad; Epistemología. 


\section{Introdução}

Em seu uso cotidiano, ou mesmo para fins acadêmicos, o conceito de religião parece ser bastante claro. Aliás, empregamos a palavra com certa desenvoltura, como se seu sentido fosse transparente para nós e para nossos interlocutores. Chegamos a constituir uma ciência que tem a religião por objeto. E ainda, mais: há quem defenda que a articulação desta ciência não se concretiza por meio da metodologia própria, mas no objeto de consideração. Assim, diferentemente de outros campos disciplinares, que se organizam em torno metodologias autóctones, o que conferiria unidade para a CR é o fato de que ela estuda, a partir de diferentes perspectivas, um objeto: a religião. Se quanto às metodologias haveria grande debate, o mesmo não se poderia dizer do objeto. A designação "Ciências da religião", a mais empregada no Brasil, é indicativa disso. Se, por um lado, o plural ciências reconhece essa diversidade de metodologias e aproximações, o singular religião põe revelo que há essa "coisa" que atende por esse nome. Nessa direção, afirma, por exemplo, Marcelo Camurça:

Desta forma, postulo então, outra perspectiva para as Ciências da Religião, em que as disciplinas das Ciências Humanas que as compõem seriam resguardadas no exercício pleno de sua autonomia teórico-metodológica, em torno de uma área (inter)disciplinar na qual o interesse comum dessas ciências seria a religião como tema (CAMURÇA, 2008, p.61).

Tanto é assim que, ao menos em nosso contexto, o conceito não é alvo de um debate mais exaustivo. Parte-se do princípio de que ele se refere a uma realidade com relativa segurança. Já faz algum tempo que a categoria do sagrado é alvo de duras críticas: Seja por sua pretensão universalista, ênfase psicologizante ou desconsideração de aspectos socioculturais, a categoria foi envolvida por certa névoa, levantando muitas desconfianças (nem todas pertinentes) sobre sua validade para a interpretação de determinados fenômenos (USARSKI, 2006, p.36). No contexto brasileiro, entrementes, chama a atenção que mesmo aqueles que se mostram mais críticos à noção de sagrado não tenham suspeitas em relação ao conceito de religião.

Quando digo que não há tantas controvérsias, com isso não quero afirmar que não se admita a numerosa variedade de possibilidades de se definir religião. Reconhece-se que estamos diante de um termo longe da univocidade. Aliás, é por assumir a complexidade desse objeto, que 
muitos apontam a necessidade de um conhecimento interdisciplinar e o emprego de diversas metodologias para se descobrir o que se guarda sob seu manto. De todo modo, o nosso ponto aqui não é estritamente esse, de se tratar de uma definição de religião. O que queremos apontar é que, não obstante as múltiplas possibilidades de definição e mesmo a sua reconhecida complexidade, admitimos muito prontamente que a noção de religião designa um território delimitado e identificável. Na esteira da crítica ideológica dos conceitos, não seria hora de nos questionarmos sobre esse conceito?

Para o senso comum, uma desconfiança em relação ao conceito religião parece até mesmo desprovida de sentido. É usual a suspeita com relação à religião. Mas, não sobre o conceito de religião. Afinal, todos sabemos o que é religião; todos temos uma resposta pronta para a pergunta sobre o que é religião. Não possuímos apenas uma resposta teórica, mas conseguimos identificá-la ao redor, diferenciando religião de outras esferas sociais, como a política, a economia, a estética, etc. Alguns se empenham, por exemplo, em mostrar o caráter opressivo e violento da religião; outros defendem a radical separação entre política e religião. Ora, para afirmar uma separação entre essas duas instâncias, é preciso que elas estejam bem delimitadas. Inclusive os cursos reconhecidos por instâncias competentes e que se ocupam desse objeto organizam congressos, conferências, debates sobre esse tema: a religião. Assim, problematizar tal noção pode soar estranho, quando não absurdo. Já não é bastante evidente que a religião está aî? Não há esse âmbito da sociedade e da cultura humana que toda gente pode ver? Também nas culturas mundo afora não é clara a forte presença dessa coisa que se chama religião?

Mas, vamos com cautela. Aliás, sugiro dar um passo atrás. Será que se pode assumir a noção de religião como algo tão natural? É assim tão óbvia? Duas observações iniciais já podem, ao menos, servir de alerta. Em primeiro lugar, uma informação básica e bastante conhecida: o termo religião é constitutivo do léxico ocidental, não encontrando correspondentes em muitos sistemas linguísticos. Isso significa, de início, que muitas pessoas são ditas "religiosas" sem conhecer nenhum termo em sua própria língua que corresponda a essa "coisa" ou região da cultura que assim denominamos.

Além disso, é importante insistir nas inúmeras definições de religião, sendo que um consenso parece distante, para não dizer impossível. Inclusive, diante dessas dificuldades, muitos foram aqueles que relegaram o problema a um segundo plano. Max Weber, por exemplo, com toda sua argúcia, quando inicia seu estudo sociológico da religião, recusa-se a defini-la. Ele diz: "Uma 
definição daquilo que "é religião é impossivel no início de uma consideração como a que se segue, e, quando muito, poderia ser dada no seu final" (WEBER, 2004, p.279). Desse modo, Weber acaba por passar diretamente para o conjunto de temas que lhe interessa, os tipos de ação comunitária, sem se delongar ou mesmo elaborar uma definição mais precisa de religião. E, ao contrário do que se poderia esperar, ele não oferece também nenhuma ao final do estudo. E não é gratuita essa omissão. Ele poderia se perder nesse labirinto conceitual sem um fio de Ariadne capaz de conduzi-lo para fora.

Por isso, neste texto, não se pretende apontar encaminhamentos, muito menos soluções. Ele se situa em um momento anterior, buscando, antes, averiguar criticamente algumas indagações em torno do tema, contentando-se tão e somente em indicar por que o conceito de religião não pode ser tomado de modo naturalizado. Por outro lado, é necessário dizer que proposições que defendem seu abandono ou substituição também encontram seus limites. Nessa direção, haveria alguma possibilidade de tratar desse tema que acate a crítica ideológica ao conceito de religião, mas que não chegue ao outro extremo de propor seu abandono?

\section{Religião como categoria moderna}

O primeiro aspecto da noção de religião é que se trata de um conceito moderno. Esse enunciado pode causar espanto, especialmente entre os mais afeitos a etimologias. Afinal, há duas hipóteses com relação à origem da palavra religião. Especialmente na modernidade, a tese de que o termo deriva de religare ganhou mais prestígio. Esta interpretação etimológica foi estimulada por autores cristãos, em especial Lactâncio (240-320) e Agostinho (354-430), que atribuíram interpretação teológica a ela, entendendo-a como religiação. No caso do cristianismo, religação entre Deus e o ser humano afastador por causa do pecado (AGOSTINHO, 1987, LV, 113). Por outro lado, há a proposta de que a palavra teria emergido do texto De natura deorum ${ }^{1}$, escrito por Cícero, identificada com relegere, isto é, reler, de modo que seu sentido se aproxima de escrupuloso, referindo-se àquele que cumpre os deveres de cultos aos deuses. Esta diferença etimológica aponta para distinção de ênfase. Enquanto o primeiro sentido centra-se no vínculo entre seres humanos e a

CÍCERO, 2016, II, XVIII. Textualmente: “Aqueles, porém, que praticam cuidadosamente tudo o que tem a ver com a louvação dos deuses e que, por assim dizer, sempre lêem por completo/sempre analisam atentamente [re-legere] são chamados 'religiosi', por derivação da palavra 'relegere' \{analisar atentamente\}". 
divindade, o segundo sentido enfatiza elementos éticos, apontando para a inserção social da religião. Com isso, não se quer dizer que na origem mais aceita não se mencione aspectos éticos e que neste segundo não se trate da relação com a divindade. Há diferença apenas de ênfase. Mas, de todo modo, o ponto aqui é: uma vez que o termo tem origem tão remota, ainda na antiguidade, como justificar que o conceito seja moderno?

Ao lado dessa indagação, pode-se colocar outra ainda mais abrangente. Já não é suficientemente claro que se pode identificar nas diversas culturas, do passado e do presente, isso que chamamos de religião? Assim, por exemplo, não falamos da religião egípcia com o tribunal de Osíris sempre pronto a julgar os que morreram? E da religião assíria com seus deuses antropomórficos? Enfim, como afirmar ser ele um conceito moderno, uma vez que se encontra por toda a parte, desde as religiões mais antigas e arcaicas à pós-modernidade?

Para avaliar essas questões em outra perspectiva, vamos adotar aqui a crítica dos conceitos que empregamos ${ }^{2}$. Em outros termos, não se trata de oferecer uma definição de religião para argumentar em seu favor. Antes, os conceitos surgem e se desenvolvem como respostas a determinadas demandas. Quando se verifica a necessidade de se empregar algum conceito, é preciso analisar a que exigências esses conceitos buscam atender. Portanto, a invenção de conceitos não é ato descolado das demandas concretas. Antes, os conceitos ao mesmo tempo em que são frutos da história, acabam também por construir a história. Portanto, mais do que o estudo etimológico, o peso das palavras se revela no seu desenvolvimento histórico. Portanto, a etimologia, por si só, pouco nos diz. É preciso estar atento ao desenvolvimento dos sentidos que o termo assume, o modo do seu emprego e, principalmente, à situação que gera a necessidade de se recorrer ao termo religião para designar uma área da vida humana. O precursor dessa tarefa foi Wilfred Smith, em O sentido e o fim da religião. A sua proposta é polêmica.

Nesse caso, poder-se-ia argumentar que a própria incapacidade persistente de clarificar o sentido da palavra "religião" sugere que se abandone o termo, que se trata de um conceito distorcido que não corresponde realmente a algo definido ou distintivo existente no mundo objetivo. Os fenômenos que

2 Nas palavras de Ivan Strenski, "Em essência, a crítica ideológica tenta entender as teorias em termos dos contextos maiores em que elas podem estar incorporadas - nas biografias e projetos intelectuais dos teóricos, em certos contextos e estratégias sociais e culturais, em contextos institucionais definitivos" (STRENSKI, 2004, p.271). 
chamamos de religiosos existem sem dúvida alguma, mas a noção de que constituem em si uma entidade distintiva talvez seja uma análise injustificada (SMITH, 2006, p.29)

Para sustentar essa perspectiva, o texto promove uma revisão nos conceitos que usualmente empregamos. Em seu estudo, Smith se empenha em mostrar como o conceito religião é de uso recente. Ele nos surpreende com algumas informações que o uso naturalizado do termo religião deixa passar impunimente. Por exemplo. É curioso observar que a Idade Média, conhecida nos livros de história por ser uma época marcada pela religião, não escreveu nenhum tratado sobre religião. Os autores medievais escreviam sumas teológicas, mas não redigiram nenhum tratado sobre religião ${ }^{3}$. Alguém poderia, nesse ponto, levantar uma objeção. E o livro de Agostinho, citado acima: Da verdadeira religião? Não seria ele um tratado medieval sobre a religião? Nesse caso, é preciso atenção ao sentido que o termo assume em seu pensamento. A nossa tendência é supor que Agostinho estabelece o contraste entre o cristianismo, como conjunto de doutrinas e práticas verdadeiras, e os outros sistemas religiosos. No entanto, sua intenção é contrastar formas de relacionamento com Deus que são verdadeiras e outras que são falsas. Sendo assim, há modos corretos e falsos de adoração, inclusive no interior do próprio cristianismo. Portanto, a noção de religião empregada aqui é muito mais no sentido de uma disposição subjetiva do que propriamente de um sistema de crenças.

$\mathrm{O}$ adjetivo religioso era utilizado no período antigo e medieval. Por exemplo, os religiosos eram pessoas que se dedicavam à vida monástica, sentido que ainda hoje nos é familiar. Religioso também é o indivíduo que segue rigorosamente alguns preceitos. Também reconhecemos esse sentido quando, por exemplo, afirmarmos que "João acorda religiosamente todos os dias às seis horas da manhã". Mas, é preciso notar que religioso aqui é adjetivo, não substantivo, ou seja, como algo que existe na cultura ou sociedade.

Ainda que os estudos etimológicos situem o surgimento do termo religião no contexto latino dos primeiros séculos da era cristã e ele seja reconhecido no período medieval, o seu uso mais recorrente acontece a partir do século XVII. Diante disso, a pergunta a ser respondida é: por que

3 Aliás, cabe ressaltar que sequer havia consenso no cristianismo medieval torno do termo de origem grega teologia. Há intensa polêmica quanto ao seu emprego. Cf. CHENU, 1953. 
o termo passa a ser utilizado com tanta frequência a partir desse momento? O que acontece nesse momento histórico que faz com que se necessite de se recorrer a ele? Não deixemos escapar um aspecto curioso. É justamente no momento em que a religião perde força, que o termo passa a ser empregado com mais frequência (SMITH, 2006, p.30). Como explicar isso?

Uma possibilidade de esclarecimento, que considero mais plausível, nos leva a considerar como a modernidade se constitui. Um de seus traços que traz profundo impacto para o entendimento da religião é a organização da vida em esferas sociais autônomas. Grosso modo, com o advento da modernidade, o dossel sagrado não se mostra mais como aquela instância que articula e organiza a vida social. Em seu lugar, há a lógica da racionalização que, com sua especialização e burocratização, conduz à concepção de sociedade a partir da diferenciação das esferas sociais. Em outras palavras, se antes da modernidade o sagrado se colocava como agente regulador, agora surgem esferas especializadas, cada qual com seu modo de legitimação próprias. Nesse movimento, o que será chamado de religião deixa de ser referência última para se tornar uma esfera ao lado de outras.

Como isso se processa? Em primeiro lugar, à medida que ocorre a racionalização da vida, as esferas sociais tendem a se tornar autônomas em relação aos valores sagrados. Assim, não se vê necessidade de recorrer à base religiosa para justificar as ações, havendo, nos dizeres de Weber, “... ausência de toda metafísica religiosa e de quase todos os resíduos de ligação religiosa”(WEBER, 1982, p.337). Em outros termos e tendo em vista a questão que aqui nos interessa, a modernidade promove a autonomização das esferas sociais. Isso significa também que, para além da referência à tradição religiosa, elas tendem a se especializar, de modo que agora é possível agora delimitar os âmbitos de cada esfera social. Assim, por exemplo, diferenciamos política e economia. Arte e erótica. De maneira ideal, identificamos certos temas e fenômenos que concernem ao que denominamos de política. Há outros, por sua vez, que se inserem naquilo que chamamos de arte. É possível haver temas comuns ou mesmo contato entre elas. No entanto, há a tendência à especialização, de modo que cada esfera dessa diz respeito a um aspecto específico da vida social, abrangendo certa área de fenômenos, valores, crenças, etc. Por exemplo, as eleições são um fenômeno político, por isso não deveria haver interferência das instituições religiosas nesse processo. Do mesmo modo, a fé é um fenômeno relativo à religião e não deveria se confundir com o direito. 
Nesse movimento de especialização, cada esfera social tende a se reger segundo sua lógica própria. Antônio Pierucci, ao comentar Weber, afirma: "Cada esfera de valor, ao se racionalizar, se justifica por si mesma: encontra em si sua própria lógica interna - uma legalidade própria [Eigengesetzlichkeit] - que a leva a se institucionalizar socialmente pela formação de seus próprios quadros profissionais, encarregados de garantir precisamente sua autonomia” (PIERUCCI, 2005, p.138). Nesse sentido, por exemplo, reconhece-se a erótica, a arte, a ciência, a economia, a ética, etc. como esferas sociais com suas lógicas próprias de legitimação. O que quer dizer essa lógica própria de legitimação? O modo como, por exemplo, se justifica uma teoria econômica é diferente da maneira como se defende uma hipótese em arte. Não faz sentido, por exemplo, pautar uma explicação para a inflação a partir de uma teoria do belo. Esta noção é aplicável ao âmbito da arte, não da economia. Do mesmo modo, não é plausível defender uma teoria científica com base no recurso à autoridade de um texto sagrado. Uma explicação científica busca amparo em provas experimentais segundo certos procedimentos metodológicos próprios ao método científico.

De todo modo, o que nos interessa aqui é ressaltar como esse processo de racionalização conduz à autonomização de esferas sociais com seus modos próprios de legitimação. Como já observado, o sagrado deixa de ser o fundo articulador da vida social. Agora, ele é rebaixado a uma esfera social ao lado das outras. E daí surge o problema: como denominar esse conjunto de ideias e práticas que lida com o transcendente, com Deus, etc? No léxico ocidental havia uma palavra para isso: religião. Dessa maneira, assim como a economia se ocupa de determinados assuntos segundo certos procedimentos, há também uma região da vida social, ao lado de outras, denominada de religião. Em outras palavras, há um âmbito da vida humana, que possui certos traços específicos passíveis de serem delimitados com relativa precisão. Esse âmbito se relaciona, mas é distinto, da política, da economia, da estética etc.

É importante acentuar isto: reconhecer que há uma esfera autônoma da vida humana com determinadas características não significa dizer que ela não mantenha relações com outras. Há, aqui, múltiplas dependências, inumeráveis relações de causa e efeito, mútuas trocas etc. Inclusive, do ponto do fiel, a dimensão religiosa acaba penetrando nas demais. Ele, por exemplo, entende a política a partir das suas crenças. Ele não é cidadão e, depois, religioso. Ele entende sua inserção no espaço público, por exemplo, a partir de sua convicção religiosa. 
Desse modo, ao se falar de autonomia, entende-se que ela se refere aos seus traços característicos e modos próprios de legitimação. Assim, por exemplo, não é pertinente recorrer, no âmbito científico, a um texto religioso como fundamentação para uma teoria científica. Do mesmo modo, há modos de legitimação tipicamente religiosos (como o apelo a uma revelação, por exemplo) que competem especificamente a esse âmbito. Por mais que se relacionem, cada qual mantém seus procedimentos próprios. Por isso mesmo soa absurdo fundamentar uma teoria científica num texto sagrado bem como deveria (!) ser estranho ancorar uma ideia religiosa numa evidência científica a fim de lhe conferir maior credibilidade.

A percepção de que há uma esfera que pode ser delimitada e nomeada de religião é resultante do processo fragmentação da vida em diversos setores, consistindo-se em um legado da modernidade, mais especificamente desse processo de racionalização. Aqui, já não é mais o religioso (ou a noção de Deus) que unifica toda a vida social. De certa forma, a partir do iluminismo, a noção cultura/sociedade vai assumindo essa função principalmente para os estudiosos ${ }^{4}$. Assim, ao menos no âmbito das ciências humanas, a ideia de sociedade ou cultura acaba sendo esse fundo que articula as demais esferas. Assim, por exemplo, podemos dizer que a economia, arte, religião, política, etc. são fenômenos culturais. Como uma parte constituinte desse todo maior que se denomina de cultura há uma região denominada de religião. Visualmente, podemos explicar isso da seguinte maneira:

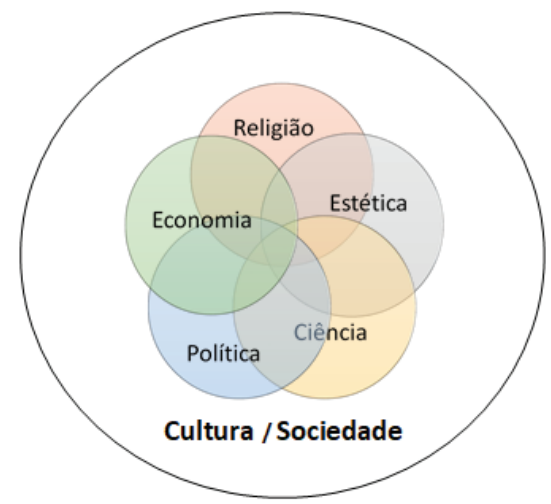

4 D. Cuche, ao analisar a gênese social da palavra e da ideia cultura, afirma: "A noção de cultura é inerente à reflexão das ciências sociais. Ela é necessária, de certa maneira, para pensar a unidade da humanidade na diversidade além dos termos biológicos" (CUCHE, 2002, p.09). 
Em outros termos, a totalidade de fundo passa a ser denominada pelo termo cultura ou sociedade, sendo compostas de várias esferas sociais autônomas. Dentre elas, uma que se denomina de religião. Uma evidência de como se passa a compreender a realidade social dessa maneira pode se encontrada no surgimento de disciplinas específicas para a compreensão de cada âmbito. É na passagem do século XVII para o XVIII que aparecem as primeiras referências à "filosofia da arte", "filosofia política" ou "filosofia da religião” (DIERKEN, 2009, p.114). Em outros termos, com o reconhecimento dessas esferas surge a necessidade de disciplinas empenhadas em compreendêlas a partir de sua especificidade. Assim, a filosofia da religião surge como tentativa de caracterizar esse âmbito específico da vida social chamado de religião. Em termos mais estritos, é partir desse contexto que emergem teorias sobre a religião, ou seja, teorias que buscam caracterizar essa esfera da vida social.

\subsection{Tendências de abordagem da religião}

A partir desse desenho, há três possibilidades de articulação do fenômeno religioso. Ele pode ser reduzido a outra esfera social. Nesse sentido, a religião teria sentido e função que não é propriamente religiosa, mas é atinente a outro aspecto. Outra perspectiva é empregar a religião como um meio para se compreender unidades maiores, como a cultura e a sociedade. E, por fim, a religião pode ser compreendia como esfera social autônoma, buscando explicar a religião a partir dela mesma.

$\mathrm{Na}$ esteira da primeira perspectiva, cabe destacar a abordagem crítica da religião (presente nos mestres da suspeita como Feuerbach, Marx, Nietzsche, Freud). Nessa tendência, busca-se explicar a religião a partir de outra esfera social. Assim, a religião não encontra legitimidade em si mesma, mas tem por referência questões outras que não propriamente religiosas. E, o objetivo do estudo da religião é reduzi-la a essas outras dimensões para que, com isso, sejam desmascarados seus reais interesses.

Assim, entende-se a religião a partir da psique, da consciência alienada ou dos mecanismos ideológicos emergentes de relações sociais desiguais, de modo que aquele que se situa fora do discurso religioso tem condições privilegiadas de decodificar a linguagem da religião, afinal a religião diz respeito ao que não é religioso. E, quem está fora da religião pode identificar com maior precisão sobre o que realmente ela trata. Ela pensa falar de Deus, mas está, na verdade, dizendo sobre pulsões, relações sociais concretas, negação da realidade, etc. 
O religioso, por não se situar numa lugar hermenêutico crítico, não consegue perceber sobre o que realmente está em operação no discurso religioso. Por isso mesmo, ela seria expressão camuflada de relações sociais desiguais ou do desemparo. Nessa tendência, uma vez resolvidos os conflitos que dão origem à religião, ela tende a desaparecer. Não havendo uma estrutura social desigual, por exemplo, a religião perderia sua função e tenderia a desaparecer. Para esses autores, não se trata de combater a religião, mas de atacar os elementos que criam as condições para que o ser humano sinta necessidade da religião. Assim, por exemplo, para Marx ou Freud não está em jogo promover uma cruzada contra a religião, mas de superar uma estrutura social ou psíquica que leva o ser humano a produzir religião. Por esse motivo, denominamos essa tendência de crítica. Ela não somente identifica a origem da religião em outra esfera social, como busca apontar caminhos para que, superadas as situações que sustentam a religião, ela seja superada ${ }^{5}$.

Outra tendência de caracterização deste âmbito da vida social, podemos chamar, na falta de um termo melhor, de funcionalista. Ao invés de perguntar pela origem da religião, a questão central é por sua função social. Em outras palavras, pressupondo essa unidade de fundo (cultura ou sociedade), indaga-se pela função que essa esfera social denominada de religião exerce nesse todo. Assim, a religião se configuraria como meio para se entender aspectos de outra unidade maior, denominada de cultura ou sociedade. O objetivo não é

5 Por exemplo, "Este é o fundamento da crítica irreligiosa: o homem faz a religião, a religião não faz o homem. E a religião é de fato a autoconsciência e o autossentimento do homem, que ou ainda não conquistou a si mesmo ou já se perdeu novamente. Mas o homem não é um ser abstrato, acocorado fora do mundo. O homem é o mundo do homem, o estado, a sociedade. Esse estado e essa sociedade produzem a religião, uma consciência invertida do mundo, porque eles são um mundo invertido. A religião é a teoria geral desse mundo, seu compêndio enciclopédico, sua lógica em forma popular, seu entusiasmo, sua sanção moral, seu complemento solene, sua base geral de consolação e de justificação. Ela é a realização fantástica da essência humana, porque a essência humana não possui uma realidade verdadeira. Por conseguinte, a luta contra a religião é, indiretamente, contra aquele mundo cujo aroma espiritual é a religião. A miséria religiosa constitui ao mesmo tempo a expressão da miséria real e o protesto contra a miséria. A religião é o suspiro da criatura oprimida, o ânimo de um mundo sem coração, assim como o espírito de estados de coisas embrutecidas. Ela é o ópio do povo. A supressão (Aufhebung) da religião como felicidade ilusória do povo é a exigência de sua felicidade real. A exigência que abandonem as ilusões acerca de uma condição e a exigência de que abandonem uma condição que necessita de ilusões. A crítica da religião é, pois, em germe, a crítica do vale de lágrimas, cuja auréola é a religião" (MARX, 2010, p.145-146). Essa afirmação de Marx é muito rica para comentarmos em todos os seus detalhes. Mas, vale destacar como ao final, ele salienta a necessidade de se abandonar as condições que conduzem a exigências por ilusões. 
entender a religião em si mesma, mas em perceber qual o papel que ela exerce no tecido social. Bryan Wilson pontua que a abordagem do sociólogo, "Difere do que eu considero ser o de religionistas comparativos [cientistas da religião] porque o sociólogo tem o compromisso final de explicar a religião por referência a proposiç̃oes teóricas amplas sobre a sociedade (...) [O sociólogo] procura encontrar, sob a superposição do estilo e conteúdo cultural especifico, principios estruturais sociais"(WILSON, 1982, p.20). Ou ainda, no dizer de Paula Montero: "Os fenômenos religiosos interessam-me, não como um campo em si mesmo de investigação, mas como via de acesso à compreensão da sociedade brasileira" (MONTERO, 1999, p.329). Em suma, nessa perspectiva, a religião é espécie de meio para se chegar a um fim. Não se trata de abordar a religião em si, mas à medida que se aborda seu papel na sociedade, ela abre caminho para se alcançar o objetivo maior que é a compreensão da sociedade/cultura.

Por fim, coloca-se outra perspectiva que busca entender a religião a partir de si mesma. Nesse caso, a tentativa é tratar a religião como tendo origem e função distintivamente religiosa, ou seja, examinar a religião em "escala religiosa". Em outros termos, reconhece-se a religião como esfera social com aspectos peculiares e que, portanto, exigiria aproximação própria, buscando captar aspectos distintivos dessa esfera em relação às demais. Termos como sagrado, por exemplo, aparecem como tentativa de denominar aspectos distintivos dessa esfera social. Mais uma vez, cabe ressaltar que afirmar autonomia dessa esfera social não significa dizer que ela independente das demais ${ }^{6}$. Ela se rege segundo regras próprias (portanto, autônoma), mas mantém relações com as demais. Isso fica evidente em várias passagens de teóricos dessa tendência ${ }^{7}$. No início do século XX, alguns autores, dentre eles R. Otto e M. Eliade, buscaram um fundamento transcendental para esse aspecto sui generis da religião. Ele se basearia numa categoria a priori do ser humano. Mais recentemente, mesmo aqueles que buscam preservar

\footnotetext{
6 Essa sobreposição entre autonomia e independência está presente em, por exemplo, Usarski. "Esta ideia culminou na definição da religião como um fenômeno sui generis, como entidade ontologicamente independente e não condicionada" (USARSKI, 2008, p.92). O autor tem razão ao se referir a abordagens mais clássicas que buscavam, inspirados por Kant, uma fundamentação transcendental para ela.

7 Nas palavras de M. Eliade, “Querer delimitar este fenômeno pela fisiologia, pela psicologia, pela sociologia e pela ciência econômica, pela lingüística e pela arte, etc... é trai-lo, é deixar escapar precisamente aquilo que nele existe de único e irredutível, ou seja o seu caráter sagrado. É verdade que não há fenômenos religiosos puros, assim como não há fenômeno única e exclusivamente religioso" (ELIADE, 2002, p. 1).
} 
a especificidade da religião, abandonam essa tentativa de fundamentação, afirmando esse como um princípio axiomático ${ }^{8}$.

É importante notar que, no limite, as questões diretivas dessas tendências são muito próximas. Em todas elas, busca-se compreender a origem e o papel desempenhado pela religião no mundo humano. Portanto, penso que se trata de superar uma divisão que muitos utilizam em relação às teorias das religião, como se elas fosse ou essencialistas ou funcionalistas ${ }^{9}$. A diferença se encontra em outro lugar, na finalidade: no primeiro caso, a religião é explicada a partir de outra esfera, enquanto em outro a religião é meio para se entender um aspecto que não é propriamente religioso (a cultura, a sociedade), por fim, a religião é a meta final na compreensão, entendida a partir de si mesma. A religião tem origem em algo religioso, de modo que cabe investigar justamente o que caracteriza esse religioso (seja ele denominado de força, hierofania, mysterium tremendum et fascinans, etc).

Essas tendências de compreensão não são coesas. Dentro de cada uma, há diversas abordagens, muitas vezes, conflitantes entre si. Elas, de certa maneira, acabam repercutindo certa divisão que se instituiu na interpretação da religião: uma vez que a religião se configura como âmbito autônomo, seria possível abordá-la a partir de seus aspectos mais exteriores. Desse modo, investe-se na sua abordagem como expressão da cultura, das relações sociais, da psique, etc. Ao lado disso, entretanto, constitui-se outro modo de interpretar a religião que enfatiza mais propriamente o aspecto interno ao discurso religioso e à subjetividade. Ela não diz respeito somente a esses aspectos mais visíveis da religião, mas se liga à interioridade do sujeito, à experiência religiosa.

Tal compreensão da religião como experiência se deve a dois movimentos complementares. De um lado, o protestantismo liberal encontra nesse recurso um meio de mostrar a pertinência da religião, livrando-a da

8 Essa perspectiva é defendida no texto de D. Pals $(1987,1990,1991)$. A sua defesa do caráter sui generis da religião deu início a um importante debate em torno da questão. Enquanto alguns se alinharam a ele (DAWSON, 1990), outros professores de Religious Studies defenderam a necessidade de se reduzir a religião a outros fatores que não religiosos (SEGAL, WIEBE, 1989, WIEBE, 1990).

9 Eliade, tido como um essecialista, ao trabalhar o simbolismo religioso oferece uma definição, mas também se preocupa em indicar as funções dos símbolos. ELIADE, 1996 p.128ss. 
crítica do empiricismo do século XIX (cf. SHARF, 1998, p. 94 - 107) ${ }^{10}$. O argumento é o seguinte: os defensores da religião argumentam que não se deveria, simplesmente, descartar a religião com base num empiricismo. Isso porque ela não se submete aos ditames e às regras da objetividade científica. Afinal, a religião tem a ver com outra coisa: ela se articula com uma dimensão subjetiva que não pode ser avaliada segundo os critérios da objetividade científica. Isso não significa que ela não seja válida. Apenas que se situa para além daquilo que pode ser objetivado pela linguagem analítica da ciência. Portanto, a religião tem sua pertinência, desde que corretamente considerada, ou seja, quando abordada em sua dimensão própria, atinente à interioridade do sujeito.

Por outro lado, para além dos interesses dos defensores da religião, essa subjetivação também atendia aos interesses liberais de privatização da religião, de modo que essa inconveniente esfera social não viesse a se intrometer em outros âmbitos. Quer dizer: a religião não teria o direito de intervir na esfera pública, mas deveria se contentar em ser questão de consciência de cada um, restringindo-se ao âmbito privado. Nessa direção, alguns autores entendem que "no caso de 'religião', a formulação da categoria tem mais a ver com interesses normativos da modernidade do que com as motivações intelectuais ou teóricas dos estudantes de religião" (ARNAL, 2013, p.59) ${ }^{11}$. Nessa perspectiva, o conceito de religião atende aos interesses do estado moderno, sendo também categoria prescritiva política, para atender às demandas de atomização do indivíduo. Por isso mesmo, a religião é tida como questão privada, que concerne às escolhas de cada indivíduo. A ênfase romântica no sentimento (Gefübl), mesmo tendo em vista outros objetivos, acaba por reforçar essa percepção.

Enfim, apesar de à primeira vista causar estranheza, pode-se notar com essa argumentação como a religião, não obstante sua origem etimológica distante, pode ser interpretada como categoria moderna. Tanto na versão

\footnotetext{
10 Schleiermacher, por exemplo, encontrara como saída a afirmação do sentimento imediato de dependência, que desperta uma certeza indemonstrável (SCHLEIERMACHER 1989, Parágrafo 108).

11 Segundo Asad, "Ainda a insistência que a religião tem uma essência autônoma - que não é confundida com a essência da ciência, da política ou do senso comum - nos convida a definir religião (como qualquer essência) como fenômeno transhitórico e transcultural. Pode ser uma feliz coincidência que esse esforço de definir religião convirja com a demanda liberal de nossa época que ela deve ser mantida separada da política, do direito e da ciência - espaços nos quais varidades de poder e razão articulam nossa distintiva vida moderna" (ASAD, 1993, p.28)
} 
de se constituir como uma esfera social como no sentido de estar restrita à subjetividade.

\subsection{Religião como categoria não nativa}

Como consequência, religião não é uma categoria "nativa" (SMITH, 1998, p.269). Com isso, quero dizer o seguinte: a consciência religiosa tende a não entender a sua própria vivência a partir desse conceito. Em parte isso deve ao fato de que a consciência religiosa experimenta sua vivência como singular e exclusiva. Nessa direção, um conceito que insere essa vivência num conjunto mais amplo de fenômenos, comum a outras culturas, acaba a destituindo de sua singularidade e exclusividade. É como se essa noção mais ampla não captasse um aspecto que é de crucial importância para o religioso: a singularidade de sua experiência que, para ele, não é comparável com nenhuma outra.

Além disso, está pressuposto na noção de religião, enquanto categoria moderna, que ela é criação do ser humano. Assim como o ser humano faz obras de arte, cria instituições políticas, ele inventa a religião ${ }^{12}$. De todo modo, uma vez que o conceito de religião a entende como produto da criação humana, ele causa desconfiança à consciência religiosa, para quem o que está em jogo é a manifestação de outra realidade por meio de elementos do cotidiano.

Não raras vezes, nessa direção, o termo religião é utilizado como meio de desqualificar a fé alheia. Enquanto uma é manifestação autêntica da divindade, a outra é expressão do ser humano que cria a divindade à sua imagem e semelhança. Não é gratuito o fato de que, no âmbito da teologia

12 Paul Tillich, em $A$ superação do conceito de religião na filosofia da religião (1922), menciona quatro reduções às quais o conceito de religião submete a religião: 1)O conceito de religião faz com que a certeza do incondicionado (de Deus) fique na dependência do ego; 2)Deus é tido como relativo ao mundo; 3)A religião é relativa à cultura, como uma função do espírito humano ao lado de outras; 4)A revelação é relativa à história da religião. Ao ser reconhecida como reduzida à subjetividade, como artefato cultural, a religião é tida como uma função do espírito humano entre outras. Assim, como o ser humano teria uma faculdade moral, estética ou de valores, ele possui uma faculdade religiosa. Deste modo, ao se restringir a religião ao sentimento (Gefühl - Scheleiermacher) ou a um a priori (Troeltsch e Otto) ou mesmo como categoria mais elevada de ação, "O incondicionado é posto lado a lado com o condicionado" (TILLICH, 1973, p.123). Assim como uma pessoa pode agir do ponto de vista ético, social, econômico etc. age também do ponto de vista religioso. Novamente, o incondicionado é perdido, e a religião é transformada em mera esfera de ação social ao lado de outras. É apenas mais uma função do espírito humano e, portanto, perde seu caráter de incondicionado. 
cristã, a tendência denominada de teologia dialética resistir ao emprego do termo religião para se referir ao cristianismo. Se a religião é construto humano, a revelação cristã não poderia se enquadrar nessa noção, pois, para alguns desses teólogos, no cristianismo não é o homem, mas Deus quem fala. Karl Barth, por exemplo, numa obra em que estabelece o contraste entre revelação e religião, associa a última à incredulidade. Textualmente, afirma: "A religião é incredulidade. A religião é conjuntura. É preciso dizê-lo com toda a clarez̧a: é o fato do homem sem Deus" (BARTH, 2011, p.41).

Em suma, aonde chegamos com essa discussão? De tudo isso, interessanos ressaltar que o conceito de religião é muito mais recente do que se está disposto assumir. Apesar da palavra ser conhecida há muito, o conceito de religião é constituído a partir de interesses e problemáticas circunscritas a um determinado contexto histórico recente, mais especificamente na modernidade ocidental. Conforme observa Wilfred C. Smith, "em todo caso, não é totalmente estulto sugerir que o surgimento do conceito 'religião' está de alguma forma correlacionado com um declinio na prática da religião em si” (SMITH, 2006, p.30). Em sua perspectiva, justamente quando a vivência religiosa se enfraquece com o processo de secularização e passa ser uma esfera social ao lado de outras, é que o termo se torna mais empregado. Pelo que expusemos até aqui, fica claro porque as coisas devem ser desse jeito. Afinal, se o conceito de religião surge justamente para delimitar uma esfera social em relação a outras, espera-se que justamente nesse contexto ela seja empregada com mais recorrência, assumindo importância maior e contornos mais definidos. Até mesmo porque, esse conceito é uma das noções utilizadas para dar expressão a esse processo.

Dessas observações, pode-se notar que uma solução que se tem adotado recentemente não resolve o problema. Muitos pensam que o simples recurso ao plural ("religiões") torna o conceito menos situado e mais atento à pluralidade, o que não aconteceria com sua versão no singular (MIELE; POSSEBON, 2012, p.403-431). Ainda que intente dar relevo à diversidade, o emprego do plural apenas indica que há exemplares diversos daquilo que se denomina de religião. Em outros termos, é somente a partir de um conceito de religião que se pode afirmar que há religiões. Dessa maneira, o plural não toca no coração mesmo da questão. Isso pode ser visto, por exemplo, na seguinte afirmação de John R. Hinnells, na abertura do Routledge Companion to the Study of Religion: 
Não há tal coisa como "religião", há apenas religiões, isto é, pessoas que se identificam como membros de um grupo religioso, cristãos, mulçumanos, etc. Uma ação ou um pensamento é religioso quando a pessoa implicada pensa que eles estão praticando sua "religião". Organizações são religiosas quando as pessoas envolvidas pensam que elas funcionam religiosamente [...] minha posição geral nessa discussão é que as pessoas são aquilo que elas acreditam que são (HINNELS, 2005, p.06).

Em busca de uma postura mais abrangente e aberta, John R. Hinnells parece não levar a crítica acima às últimas consequências. Em primeiro lugar, como se observou, cabe lembrar que o conceito de religião não é nativo; ele surge muito mais a partir de demandas historicamente situadas em um momento de enfraquecimento da presença da religião (i.e., secularização), de modo que nem todas as pessoas, ações, pensamentos ou instituições que são denominadas religiosas se entendem a si mesmas dessa maneira. Em segundo lugar, designá-las como religiosas somente é possível, justamente, por se pressupor um conceito de religião que permite estabelecer tal distinção. Sem um conceito de religião (no singular), como distinguir entre uma instituição política e uma religiosa? Aliás, como posso identificar uma instituição ou prática como religiosa se já, de antemão, não possuir minimamente uma definição prévia de religião? Como posso designar budismo como religião e aristotelismo como filosofia sem uma distinção de fundo entre religião e filosofia? Simplesmente por que as pessoas assim a designam? Como se pode dizer que há religiões concretas sem pressupor um conceito de religião? Para que seja possível designar hinduísmo, cristianismo, islã, etc. como tradições religiosas, pressuponho um conceito de religião e que permite inserir essas formas de pensamento e comportamento nos auspícios da religião. Enfim, somente posso falar de religiões porque há um conceito de religião de fundo.

\section{A proposta de abandono do termo religião e seus limites}

Do ponto de vista dos críticos, uma consequência decorrente do caráter situado do conceito de religião é que ele, em vez de promover abordagens transculturais simétricas, acaba efetuando, justamente, o contrário: enquanto legatário da compreensão de mundo ocidental moderna, esse conceito normativo se configuraria, precisamente, como um entrave, reverberando ainda as intenções colonialistas do Ocidente. Nesse sentido, Timothy Fitzgerald afirma: 
A construção de "religião" e de "religiões" como objetos de estudo global, transcultural, é parte de um processo histórico mais amplo do imperialismo, colonialismo e neocolonialismo ocidentais. Parte desse processo foi estabelecer uma distinção ideologicamente carregada entre o reino da religião e o reino da não-religião ou secular (FITZGERALD, 2000, p.08).

Assim, o termo não seria meramente descritivo, mas buscaria prescrever uma distinção entre secular e religioso, evidenciando-se como meio de imposição de compreensão ocidental a outras culturas que não se entendem dessa mesma maneira. Por exemplo, em uma cultura que não se concebe fragmentada em esferas sociais autonomamente constituídas, que sentido faz afirmar a existência de um campo delimitado e qualificado como religioso? Haveria, no fim, uma tentativa de imposição de um conceito exógeno a outros sistemas culturais e linguísticos com autocompreensão muito diferente do Ocidente.

Obviamente, isso depende do que se entende por uma abordagem transcultural. Ela pode, por exemplo, ser interpretada como interpelação do outro. Devido ao vínculo que toda abordagem possui com a tradição da qual é legatária, é preciso reconhecer que esse diálogo se constitui a partir de um conjunto de sentidos previamente estabelecidos. Eles podem ser revistos, ampliados e reavaliados. No entanto, um diálogo autêntico implica em assumir que se interpreta as coisas a partir de algum lugar. Esse lugar é, devido à finitude e historicidade constitutiva do ser humano, sempre situado. O ponto está justamente em que medida se reconhece ou não a historicidade dos termos do diálogo. Caso eles sejam tomados como espelho da realidade, não há espaço para que sejam revisitados. No entanto, se eles são tidos como fundamentos hermenêuticos, eles, simultaneamente, fornecem uma referência a partir de onde interpretar o mundo, - mas também reconhecem que são uma interpretação do mundo e, portanto, são passíveis de revisão. Desse modo, religião (assim como sociedade, cultura, classe, etc.) pode ser tida, em outra chave, como categoria que possibilita o diálogo com outras "culturas".

Diante dessas e outras dificuldades, alguns estudiosos, seguindo os passos inaugurados por Wilfred C. Smith, sugerem uma solução radical: o abandono da palavra religião. Uma vez que o termo se mostra, por demais situado, sendo constituído a partir de problemas e interesses do iluminismo e propiciando uma concepção deturpada da realidade, não faria mais sentido seguir utilizando-o. Para citar aquele que foi um dos pioneiros nessa proposição: 
Neste caso, poder-se-ia argumentar que a própria incapacidade persistente de clarificar o sentido da palavra "religião" sugere que se abandone o termo, que se trata de um conceito distorcido que não corresponde realmente a algo definido ou distintivo existente no mundo objetivo. Os fenômenos que chamamos de religiosos existem sem dúvida alguma, mas a noção de que constituem em si uma entidade distintiva talvez seja uma análise injustificada (SMITH, 2006, p. 29).

Em outros termos, uma vez que essa coisa chamada religião não existe objetivamente, o conceito fornece uma imagem distorcida da realidade. Por isso mesmo, ele não apenas deve ser colocado sob suspeita, mas abandonado. Com peculiaridades próprias de suas análises, W. Arnal e R. McCutcheon sugerem algo parecido. Em vez de se investigar isso que se alcunhou de religião, e que se encontra espalhado nas diversas comunidades humanas, os autores insistem que se inquira o que levou, nos últimos séculos, a se denominar parte da vida cultural humana com o conceito de religião. Nesse sentido, por meio da historicização da noção, os autores apontam que essa taxinomia é historicamente e geograficamente arbitrária, servindo a interesses ligados à emergência do estado liberal moderno. $\mathrm{O}$ conceito não poderia ser tomado de maneira naturalizada, como se fosse capaz de se referir a um fato de caráter universal - e mais, os estudiosos não deveriam mais empregá-lo.

Se o conceito de religião é suspeito, imagine então como fica a pertinência de uma disciplina (ou área) que pretende se dedicar ao estudo desse objeto. Se não há algo como religião, também não faz sentido se defender a existência de um campo do saber que se dedica ao estudo desse objeto imaginário. Em termos mais claros, se não há religião, não faz sentido existir cursos de Ciência da Religião.

Antes que alguns fiquem desesperados - inclusive pelo risco de perder seus empregos -, é importante observar limites internos nessa proposta. Alguns deles são explícitos nos próprios textos daqueles que se mostram partidários de seu abandono. É bastante recorrente nos textos desses autores que, logo após proporem a despedida do termo religião, ele seja de novo convocado a comparecer. Muitas vezes, ele é expulso pela porta da frente, mas retorna sorrateiramente pelas portas dos fundos, a convite daqueles mesmos que o expulsaram. Em alguns casos, ele é vestido com aspas, como se isso o tornasse mais apresentável.

Tomemos um exemplo extraído do livro de W. Arnal e R. McCutcheon. Logo no primeiro capítulo, intitulado "Sobre a definição de religião", os 
autores estabelecem as dificuldades do conceito. No entanto, mais à frente, no mesmo livro, em um capítulo que trata do cristianismo das origens, os autores assumem que, por meio de uma tipologia, tentou-se "dar conta de dimensões centrais de um pacote variado de comportamentos que chamamos de 'religião', ou seja, as práticas e os discursos em torno do que tem sido chamado de espiritual, sobrenatural ou seres contra-intuitivos"(ARNAL, MCCUTCHEON, 2013, p.162. cf. também, p.68 e 69). Ainda que empreguem o termo religião entre aspas, nota-se que haveria um conjunto de comportamentos, especialmente relacionados com aquilo que transcende a ordem do mundo natural, que poderia ser designado religião. Dessa maneira, apesar de se defender a impertinência e o abandono do termo, ele acaba retornando para especificar certos tipos de condutas ligadas com o sobrenatural. Enfim, os próprios autores não são conseguem ser totalmente coerentes na proposição de abandono do termo.

Isso também se pode constatar na citação anterior, de Wilfred C. Smith. Ele reconhece que há fenômenos que denominamos religiosos. No entanto, como designá-los dessa maneira sem se pautar por um conceito de religião? De novo: como fixar certos fenômenos como religiosos se já não se está de posse de um conceito de religião?

É preciso entender que não se está apenas diante de uma contradição lógica, falta de cuidado editorial ou mesmo desatenção dos autores. Até mesmo porque esse tipo de procedimento é passível de ser encontrado em vários outros livros que fazem proposições parecidas. O retorno do conceito pode apenas indicar as dificuldades em se sustentar até o fim o seu abandono. Por mais que tenha suas limitações, ele parece ser relativamente útil para que se entenda ao que os autores pretendem acenar. Apesar das dificuldades em torno de sua definição, por vezes, o conceito consegue se referir a um conjunto de fenômenos para os quais se quer chamar a atenção, de modo que não se encontra outro candidato que atenda aos requisitos de preencher a lacuna deixada pelo abandono do termo.

Diga-se de passagem, em textos que seguem nessa tendência, abusam-se das aspas. O procedimento parece ser o seguinte. Em primeiro lugar, mostramse as limitações de determinado conceito (seja ele religião, Oriente, Ocidente, cultura etc.), especialmente destacando seu caráter situado. No entanto, como não se consegue referir ao conjunto de fenômenos que esses termos criticados cobrem a partir de outras noções, recorrem-se novamente a eles. Mas, com uma distinção: acrescenta-lhes aspas. É como se esse recurso gráfico solucionasse o impasse que aqui se coloca. É aquela história: o conceito é expulso pela 
porta da frente, mas é convocado a entrar pelas portas dos fundos; agora, devidamente trajado com aspas, ele parece mais aceitável. No entanto, a meu ver, esse procedimento nem de longe resolve o problema.

Um segundo movimento, que complementa esse primeiro - do abandono do conceito religião -, é a sugestão de outros conceitos, tidos como menos comprometidos historicamente e capazes de expressar com maior fidelidade a realidade que buscam descrever. O pressuposto aqui já é curioso. Expressar com maior fidelidade encontra seu correspondente em formulações menos situadas, como se o fato de ser situado é um limite e não a condição de toda e qualquer elaboração conceitual.

Se religião nos fornece uma imagem distorcida, caberia encontrar outras formulações capazes de oferecer um reflexo mais exato da realidade. Ainda que não seja avesso ao uso do termo religião, Ninian Smart enfatiza "visões de mundo", privilegiando a experiência religiosa e destacando a compreensão que se estabelece a partir de dentro da crença (SMART, 1973, p.9ss; 1969, p.1). Timothy Fitzgerald, por sua vez, sendo coerente com o não reconhecimento de que há algo sui generis na religião, propõe que o termo também seja deixado de lado, utilizando em seu lugar a noção de cultura ou mesmo de sociedade. Ele admite que esses conceitos não são isentos de dificuldades. Não obstante, contrariamente à noção de religião, eles se revelariam mais úteis, justamente, por envolver isso que se chama de religião, mas indo além (FITZGERALD, 2000, p.222).

Mas, talvez, justamente aqui, esteja a fraqueza da proposta. Cultura, por exemplo, envolve a linguagem (sonhos, convenções, artefatos materiais, estruturas de cognição), textos culturais (formas de entretenimento, dramas, tramas sociais), discursos (médicos, sexuais, etc.). Para efeitos de análise, corre-se o risco de se perder as fronteiras. Nessa noite dos conceitos, em que "todos os gatos parecem pardos", os prejuízos parecem ser maiores do que os ganhos.

Além do mais, ao se observar a análise que se desenvolve, pode-se notar que muitos dos problemas que afligiam o termo religião incidem também sobre os potenciais candidatos a substituí-lo. A noção de cultura, por exemplo, é irmã gêmea do conceito de religião, sendo gestada também no âmbito da modernidade (MASUZAWA, 1998, p.70). Quer dizer: para todos os efeitos, esse é um conceito amplo, mas igualmente situado.

As dificuldades que a noção de religião traz à tona parecem não serem superadas quando se propõe essa troca. Isso fica claro quando se volta os 
olhos para o clássico de W. C. Smith. Como bom particularista, tendo em vista a compreensão mais autêntica, ele propõe que se interprete o religioso a partir de seus próprios termos. Nesse sentido, não se estaria autorizado a empregar o termo religião ou religiões se o nativo assim não o fizer. No entanto, para ser coerente com sua proposição, ele teria de, dentro de cada sistema linguístico ou tradição "religiosa" (se é ainda permitido usar o termo), encontrar o modo como eles se referem a si mesmos. Isso não somente seria impossível, afinal implicaria o domínio de incontáveis tradições, mas também correria o risco de tornar o estudo relevante apenas para aqueles que compartilham e entendem certo quadro de referências. Diante disso, o próprio autor encaminha sua abordagem para o emprego do termo "fé". Por mais que defenda seu caráter dinâmico e histórico, não se pode abdicar de recorrer a um outro termo que, com alguns reparos, acaba por reinscrever em outra chave as limitações, muito parecidas com aquelas que afligiam o conceito de religião.

Cabe observar, ainda, que, não obstante a obscuridade que circunda o termo religião, ele continua sendo empregado por diversos teóricos. Nos últimos trinta anos, por exemplo, tem-se consolidado uma área de pesquisa denominada "cinema e religião", inclusive se valendo de abordagens mais globalizadas (MITCHELL, 2007) ${ }^{13}$. A persistência do conceito criticado não pode ser indicativo de que se não há consenso sobre o que é religião, muito menos acordo existe em torno de que outras noções poderiam substitui-lo satisfatoriamente? Essa proposta de abandono não parece ser, na prática, pouco factível?

\section{Horizontes e limites de um conceito}

Se não se pode tomar o conceito de religião de maneira naturalizada, o outro extremo, de propor seu abandono ou troca por outras noções, também se depara com consideráveis limites. Então, para onde nos leva a consideração crítica do conceito religião?

Como se tem dito, religião é tratada aqui como, antes de tudo, um conceito. A abordagem mais usual é entender que os conceitos são forjados

\footnotetext{
13 É interessante, aqui, que não se abandona o termo religião, mas apenas se observa uma variedade no modo como se entende religião. Por isso mesmo, pode-se buscar a religião nos filmes - como fez a abordagem transcendentalista (SCHRADER, 1972) - ou entender o cinema como religião (LYDEN, 2003). Aqui, novamente, se está diante de compreensões distintas (mas, não necessariamente excludentes) de religião.
} 
a partir das necessidades que a realidade empírica traz. Melhor dizendo, o desejo de compreender e dominar um conjunto de fenômenos faz com que inventemos conceitos. Eles são o modo pelo qual damos nome a acontecimentos que, de outro modo, permaneceriam desconhecidos. Assim, os conceitos estariam subordinados à realidade. Primeiro, os fenômenos aparecem. Depois, buscam-se conceitos capazes de torná-los compreensíveis, de modo que eles são tanto melhores quanto mais conseguem, de maneira adequada e precisa, se referirem a essa realidade que se coloca. Esse é o pressuposto de muitos dos autores citados nesse ensaio. Wilfred C. Smith, por exemplo, pontuava que uma das razões para se abandonar o conceito de religião seria a falta de correspondente na "realidade objetiva". J. Hinnells, por sua vez, dizia que não há algo como religião, mas apenas exemplares individuais, portanto, religiões. Ou seja, há um descompasso entre o conceito e o que ele deveria abarcar.

Certamente, os conceitos possuem também essa função - não se pretende negar essa importante contribuição que eles trazem. Muito do debate acadêmico se organiza em torno dessas balizas, na busca de conceitos capazes de dar uma melhor expressão a uma dada realidade. No entanto, é de se perguntar se um conceito se limita apenas a isso. Dizendo mais diretamente: em vez de ser meramente a descrição de um conjunto de fenômenos dados, conceituar também não comportaria em si a "condição para conceber"? Nessa perspectiva, um conceito não seria, simplesmente, um modo de referência, mas também um horizonte que permite com que os fenômenos apareçam. Os conceitos não surgem só posteriormente, a reboque da realidade empírica; antes, funcionam como meios para se acessar essa realidade empírica. Em vez de virem depois, como simples derivação da realidade dada, situam-se como condição de possibilidade para o encontro com a realidade. Eles criam espaços que permitem com que alguns fenômenos se tornem visíveis de um determinado modo.

Antes de haver conceitos que correspondem a algo já dado, há de se tratar do modo como os fenômenos se manifestam. Para que haja relação entre sujeito e objeto, é condição necessária que se estabeleça um espaço que torne possível tal encontro. Se, para haver correspondência entre o conceito e a coisa, é preciso que os fenômenos se mostrem, é pertinente que se interrogue o modo como eles se mostram. O sujeito não encontra o objeto em um vazio, de maneira pura. Antes, a relação pressupõe um "espaço" que torna possível esse encontro. Não vem ao caso se o espaço é claramente 
tematizado ou não. Ele pode estar lá e nunca ser alvo de consideração mais pormenorizada. De todo modo, os conceitos tornam possível que um conjunto de fenômenos se manifeste para alguém. Assim, eles não somente descrevem uma realidade dada, mas, primariamente, criam um espaço para que os fenômenos se tornem visíveis a partir de uma determinada maneira. O filósofo italiano Gianni Vattimo exprime isso da seguinte maneira:

Conhecer, já no nível das puras e simples percepções espaço-temporais, significa construir um fundo e um primeiro patamar, ordenando as coisas com base numa pré-compreensão que exprime interesses, emoções e que herda uma linguagem, uma cultura, formas históricas de racionalidade. As coisas aparecem - se dão como entes, "vem ao ser" - só no horizonte de um projeto, senão não se deixam nem mesmo distinguir do fundo e entre elas (VATTIMO, 2001, p.25)

Um exemplo pode nos ajudar a compreender o que aqui se coloca. Muitas vezes, tentou-se, por exemplo, elaborar um conceito de religião que seja puramente empírico. Nesse sentido, analisam-se os diversos fenômenos religiosos e, buscando apreender o que eles possuem em comum, por meio da abstração, poder-se-ia chegar a uma definição do que é religião ${ }^{14}$. Aos ouvidos de muitos, isso soa como o procedimento mais adequado, afinal o empírico daria uma base confiável para um conceito bem fundamentado de religião. No entanto, como se poderia classificar determinados fenômenos de "religiosos" se, de antemão, não se possui uma noção do que é religião propriamente dita? Como delimitar, então, um conjunto de fenômenos empíricos para se alcançar a definição de religião se, de antemão, certa compreensão do que é religião já não estivesse em operação? Como distinguir entre um partido político e um grupo religioso sem estar munido de uma noção de religião? Não se chega à noção de religião simplesmente analisando a realidade e, por meio do processo de abstração, elaborando-se um conceito de religião. Antes mesmo de interpelar a realidade empírica, o observador já se vale de um conceito; mais do que isso: é justamente esse conceito que permite com que os fenômenos religiosos possam ser interpelados enquanto religiosos.

$\mathrm{Na}$ hermenêutica, isso é denominado de concepção prévia. O conceito previamente formulado torna um conjunto de fenômenos visível de determinado modo. Nesse sentido, o termo horizonte parece ser bastante

14 De certa maneira, essa perspectiva aparece em alguns pais fundadores da ciência da religião. Cf. TIELE,1897, p.08 e p.302. 
adequado. O horizonte implica um campo de visão que se abre. Ele cria esse espaço que permite com que certos fenômenos possam se manifestar. Mas, não se deve esquecer que o horizonte se depara com um limite. Ele consegue ver apenas uma parte. A totalidade não lhe é acessível. O mesmo ocorre com os conceitos. Abrir um horizonte significa dizer que ele traz certa face de alguns fenômenos à luz, deixando outros tantos às sombras. Eles são, portanto, limitados. Wittegenstein expressou essa noção de maneira bastante sucinta, ao afirmar que: "Os limites da minha linguagem denotam os limites do meu mundo” (WITTGENSTEIN, 1997, p.111).

Para nossa problemática, isso quer dizer que os conceitos não são apenas nomes para uma realidade dada, mas que toda experiência já é mediada pela linguagem, que abre um mundo que torna possível a interpelação de determinados fenômenos. Assim, mais do que ser expressão compreensiva de uma realidade dada, o acesso a determinado conjunto de fenômenos é possibilitado pelos conceitos.

Nessa medida, parece ser muito apressado dispensar um conceito porque ele simplesmente não corresponde a uma realidade objetiva. É claro que não há algo como a "religião" no mundo objetivo. Mas, o que esse conceito nos proporciona é, justamente, o acesso a elementos que denominamos religiosos. Como interpelar uma religião específica sem esse conceito mais amplo de fundo? Esses conceitos não deveriam ser avaliados unicamente pela sua capacidade de descrição ou de se referir a fatos. Antes, eles deveriam ser perguntados sobre em que medida e onde abrem ou limitam o pensar.

O mérito da desconstrução do conceito de religião está, então, em indicar que a noção de neutralidade no estudo da religião é falaciosa. Muitas vezes já se disse que a ciência da religião, ao contrário da teologia, manteria certa neutralidade em relação ao seu objeto (WRIGHT, 2007, p.21ss). Enquanto a teologia seria normativa e teria uma abordagem por demais comprometida com certos pressupostos e certa tradição religiosa, as demais ciências humanas (incluída, nesta lista, a Ciência da Religião) poderiam sustentar um olhar mais neutro, imparcial, objetivo, sem comprometimento ou engajamento religioso etc. Aliás, as abordagens que assim se classificavam consideravam-se mais autenticamente acadêmicas.

No entanto, o reconhecimento do caráter situado de conceitos chave (religião, cultura, sociedade) chama a atenção de que não há essa neutralidade. Aliás, seria melhor se ao invés de falar neutralidade, empregássemos o termo distanciamento. Não há possibilidade de neutralidade, isto é, de se analisar 
as coisas sem um comprometimento com uma rede de sentidos previamente estabelecidos e a partir da qual se pensa. Seja para reafirmar ou para negar esses sentidos, eles se constituem como referências. A análise da história dos conceitos mostra, justamente, como eles são forjados a partir de interesses, objetivos, sentidos prévios, ideologias etc. Desse modo, contrapor neutralidade com engajamento não é um caminho muito produtivo. $O$ que se pode exigir do pesquisador é, mais precisamente, distanciamento, para que aquilo que se estuda possa se constituir como objeto; afinal de contas, algo só pode aparecer a alguém como um objeto caso esteja colocado a certa distância. Se algo se encontra muito perto de meus olhos, o que se consigo ver são borrões. É preciso, portanto, certa distância para que uma coisa se constitua como objeto. O mesmo vale para o estudo da religião. Quer dizer, é preciso considerar, fortemente, que os conceitos carregam as marcas da finitude de quem os construiu. Isso, por si só, não seria negativo, tendo em vista que os conceitos e sua desconstrução não estão igualmente situados? O ponto é, na medida do possível, ter clareza sobre esses pressupostos, a fim de não se pensar que determinada interpretação ou lugar hermenêutico teria condições de se mostrar como não-lugar, como ponto de vista não comprometido e, portanto, mais objetivo.

No entanto, no que concerne a esse ponto, parece que há um descompasso em parte da reflexão acadêmica contemporânea. De um lado, há certa benevolência em se reconhecer que toda leitura é situada, que os termos carregam uma história, interesses, objetivos, ideologias etc. Mas, por outro lado, buscam-se conceitos que sejam cada vez menos comprometidos temporalmente, capazes de se referir com maior precisão a uma realidade dada. De um lado, chama-se a atenção para o caráter situado de toda a abordagem. Ela se dá a partir de um horizonte de compreensão histórico, com o comprometimento dos conceitos com certo horizonte de sentido. No entanto, parece que ainda se almeja chegar à coisa em si, isto é, pressupõe que o fenômeno já está sempre disponível, há uma "realidade dada". Com isso, não se assumem as consequências mais radicas da hermenêutica. Um dos ganhos foi justamente mostrar que não há algo que se dá numa presença inquestionável, de maneira que o grande problema não seria somente encontrar o melhor termo para expressar essa realidade dada. Se não há fatos, mas somente interpretações, é preciso assumir que temos acesso a sentidos a partir de uma rede de significados. Isso quer dizer que se está sempre interpretando, não espelhando uma realidade. Essa interpretação se funda 
justamente numa horizonte temporalmente formado e que, portanto, não se comporta como mera transposição ou espelhamento "da realidade". Antes, a realidade sempre se mostra a partir de um fundo, de uma herança. Somente temos acesso a ela por meio de mapas, de conceitos herdados.

Em outros termos, o que se pretende dizer é que toda abordagem parte de um horizonte hermenêutico. Isto é, o diálogo com o passado ou com outras tradições se constitui a partir de uma rede de significados no qual o intérprete está inserido. É a partir dela que ele pode se aproximar do outro, seja ele um texto, um grupo religioso ou uma tradição distinta da sua. Nessa rede de significações, os conceitos são importantes. Ao mesmo tempo em que, como ponte que interligam dois territórios, eles funcionam como mapas que abrem um campo possível para o pensamento. Ora, as pontes são sempre muito mais estreitas do que o rio que pretende ultrapassar e os territórios que pretende ligar. No entanto, caso se queira atravessar o rio, elas se mostram úteis, mesmo não cobrindo toda a imensidão das águas ou a amplitude do território.

Nesse sentido, os conceitos também são mapas que servem de guia, mas que nunca correspondem exatamente ao território que pretendem indicar. Até mesmo porque um mapa que correspondesse inteiramente ao território seria inútil. O que torna um mapa produtivo é que ele se refere ao território, interpreta-o, concede uma unidade ao conjunto de cordilheiras, rios, planícies, etc., de modo a nos fornecer subsídios suficientes sobre a direção que devemos tomar, por onde nos movimentar e como chegar ao ponto pretendido. Eles não cobrem exatamente o território, mas permitem que, de uma visada, seja possível perceber uma unidade na imensidão do espaço real. Claramente, o mapa não é o próprio território. Antes, o mapa apenas aponta para o território a ser explorado. Por isso mesmo, ele abre um espaço, torna determinado território passível de ser atravessado. Em outros termos, um conceito não é apenas expressão de uma realidade, mas possibilita o acesso a essa realidade. Para conceder unidade ao território ele é, necessariamente, reducionista.

Para o viajante, o mapa precede o território e ele pode ser corrigido à medida que se nota as discrepâncias entre a topografia e as indicações do mapa. Ao se deparar com o objeto de estudo, ele pode chamar a atenção para os limites do conceito. O conceito somente pode ser concebido como imposição no caso de não reconhecer a necessidade constante de ser revisitado e revisado segundo algumas demandas que o próprio objeto traz. 
É possível e desejável que esse conceito esteja de tal modo aberto a ponto de ser reformulado. Mas, de todo o modo, o ponto de partida se encontra em noções previamente estabelecidas. Isso faz parte da finitude constitutiva de ser humano lançado em uma rede de significações, num horizonte hermenêutico. Os conceitos são o ponto de partida, tornando-se violentos e impositivos quando não se permitem ampliar ou se rever. Desse modo, a limitação constitutiva de todos eles não é, necessariamente, ruim. Antes, oferecem um chão a partir de onde se pode interpretar.

\section{Conclusão}

Esse artigo pretendeu tratar de um conceito chave para os estudos de religião, especialmente para a ciência da religião. De um lado, é preciso reconhecer os méritos da crítica ideológica dessa noção. Religião não é algo "natural", mas aparece numa configuração histórica bem precisa, visando atender certas demandas. Para alguns teóricos, o reconhecimento desse caráter situado leva à proposição do abandono do termo. No entanto, essa solução radical tem suas limitações. Ela não consegue se manter coerente até o fim e o conceito acaba retornando pelas portas dos fundos.

Sendo assim, como considerar a crítica ideológica do conceito mas, sem incorrer nas contradições da solução radical de abandono da noção de religião? Para sair desse impasse, recorreu-se à noção de horizonte hermenêutico. De um lado, é precios reconhecer o caráter situado dessas noções. No entanto, ao invés disso ser algo negativo, é a condição que possibilita a abordagem de fenômenos.

Enfim, à luz dessas considerações, empregar o conceito religião de maneira naturalizada ou propor a sua dispensa porque ele não descreve algo objetivo ou porque ele é situado, não parece ser (ao menos) uma decisão por demais apressada?

\section{Referências}

AGOSTINHO. A verdadeira religião. São Paulo: Paulinas, 1987.

ARnAL, William; MCCUTCHEON, Russel. The Sacred is the Profane. The Political Nature of "Religion”. Oxford: Oxford University Press, 2013

ASAD, Talal. Genealogies of Religion. Discipline and reasons of power in Christianity and Islam. Baltimore and London: The Johns Hopkins University Press, 1993

BARTH, Karl. Revelação de Deus como sublimação da religião. São Paulo: Fonte Editorial, 2011. 
CAMURÇA, Marcelo. Ciências sociais e ciências da religião. São Paulo: Paulinas, 2008.

CHENU, M.-D. La théologie au XIIème siècle. Paris: Cerf, 1953.

CÍCERO. De Natura Deorum. Trad. Bruno Bassetto. Uberlândia: Edufu, 2016.

CUCHE, Denys. A noção de cultura nas ciências sociais. Bauru: EDUSC, 2002.

DIERKEN, Jörg. "Teologia, ciência da religião e filosofia da religião: definindo suas relações”. In: Veritas. No 1, vol. 54, 2009. Disponível em: http://revistaseletronicas.pucrs.br/ojs/index. $\mathrm{php} /$ veritas/article/view/5071 (visitado em 04/10/2018)

ELIADE, M. Observaciones metodológicas sobre el estudio del simbolismo religioso. In: ELIADE, M; KITAGAWA, J. Metodología de la historia de las religiones. Barcelona: Paidos, 1996

Tratado de história das religiões. São Paulo: Martins Fontes, 2002.

FITZGERALD,T. The Ideology of Religious Studies. Oxford: Oxford University Press, 2000.

HINNELS, John. The Routledge Companion to the study of religion. London/New York: Routlegde, 2005.

LYDEN, John. Film as religion. Myths, morals and rituals. New York: NYU Press, 2003

MARX, K. Crítica da filosofia do direito de Hegel. São Paulo: Boitempo, 2010.

MASUZAWA, Tomoko. "Culture". In: TAYLOR, Mark C. (Ed.) Critical terms for Religious Studies. Chicago: Chicago University Press, 1998.

MIELE, Neide; POSSEBON, Fabricio. Ciências das Religiões: proposta pluralista na UFPB. In: Numen, vol. XV, no.02, 2012, p.403-431.

MITCHELL, Jolyon. The Religion and Film Reader. New York: Routledge, 2007.

MONTERO, Paula. Religião e dilemas da sociedade brasileira. In: MICELI, Sérgio. O que ler em ciência social no Brasil. Caxambu: ANPOCS, 1999.

PALS, Daniel L. Is Religion a Sui Generis Phenomenon? In: Journal of the American Academy of Religion, volume LV, número 2, 1987, p. 259-284.

Colloquium: does Autonomy Entail Theology? Autonomy, Legitimacy, and the Study of Religion. In: Religion, 20, 1990, p.1-16.

Responses and Rejoinders. In: Journal of the American Academy of

Religion, volume LIIX, número 4, 1991, p. 703-714.

PIERUCCI, Antonio Flávio. O desencantamento do mundo. Todos os passos do conceito em Max Weber. São Paulo: editora 34, 2ª Edição, 2005.

SEGAL, Robert; WIEBE, Donald. Axioms and Dogmas in the Study of Religion. In: Journal of the American Academy of Religion, Volume LVII, número 3,1989, p.591-605.

SCHLEIERMACHER, Friedrich. The Christian Faith. Edinburgh: T. \& T. Clark, 1989.

SCHRADER, Paul. Transcendental Style in Film: Ozu, Bresson, Dreyer. Berkeley: University of California Press, 1972 
SHARF, Robert. Experience. In: TAYLOR, Mark C. Critical Terms for Religious Studies. Chicago: The University of Chicago Press, 1998, p. $94-107$

SMART, Ninian. The Phenomenon of Religion. New York: The Seabury Press, 1973 The Religious Experience of Mankind. New York: Charles Scribner's Sons, 1969 , p.1.

SMITH, Jonathan Z. Religion, Religions, Religious. In: TAYLOR, Mark C. (Ed.) Critical terms for Religious Studies. Chicago: Chicago University Press, 1998

SMITH, Wilfred C. O sentido e o fim da religião. São Leopoldo: Sinodal, 2006.

STRENSKI, Ivan. Ideological Critique in the Study of Religion Real Thinkers, Real Contexts and a Little Humility. In: ANTES, Peter, GEERTZ, Armin W., WARNE, Randi R. New Approaches to the Study of Religion. Volume 1: Regional, Critical, and Historical Approaches. Berlin /New York: Walter de Gruyter, 2004

TIELE, C. P. Elements of the Science of Religion. Vol. I, London: William Blackwood and Sons, 1897

TILLICH, Paul. Filosofía de la religión. Trad. de Marcelo Pérez Rivas. Buenos Aires: Ediciones Megápolis, 1973

USARSKI, F. Perfil paradigmático da ciência a religião na Alemanha. In: TEIXEIRA, Faustino. A(s) ciência(s) da religião no Brasil. São Paulo: Paulinas, $2^{a}$ ed., 2008

Constituintes da ciência da religião. São Paulo: Paulinas, 2006.

VATTIMO, Gianni. A tentação do realismo. Trad. Reginaldo di Piero. Rio de Janeiro: Instituo de Cultura Italiana, 2001

WEBER, M. A psicologia social das religiões mundiais: In: Ensaios de sociologia. 5 ed. Rio de Janeiro: Zahar, 1982.

"Sociologia da religião (tipos de relações comunitárias religiosas)". In: Economia e Sociedade. Vol. 1. Brasília: UNB e Imprensa oficial, 2004.

WIEBE, Donald. Disciplinary Axioms, Boundary Conditions and the Academic Study of Religion: Comments on Pals and Dawson. In: Religion, 20, 1990, 17-29

WILSON, Bryan. Religion in Sociological Perspective. Oxford: Oxford University Press, 1982 WITTGENSTEIN, Ludwig. Philosophical Investigations. Oxford: Blackwell, 2a edição, 1997 WRIGHT, Melani. Religion and Film. New York: I.B. Taurus, 2007.

Submetido em: 5-10-2018

Aceito em: 20-4-2019 